\title{
NEUROPATHY - EXPONENT OF ACCELERATED INVOLUTION IN UREMIA: THE ROLE OF CARBAMYLATION
}

Tatjana Lazarevic, Zoran Kovacevic

${ }^{1}$ University of Kragujevac, Faculty of Medical Sciences, Department of Internal medicine, Serbia

${ }^{2}$ Clinical Centre Kragujevac, Kragujevac, Serbia

\author{
NEUROPATIJA - EKSPONENT UBRZANE INVOLUCIJE U UREMIJI: \\ ULOGA KARBAMILACIJE \\ Tatjana Lazarevic, Zoran Kovacevic \\ ${ }^{1}$ Univerzitet u Kragujevcu, Fakultet medicinskih nauka, Katedra za internu medicinu, Kragujevac, Srbija \\ ${ }^{1}$ Klinički centar Kragujevac, Kragujevac, Serbia
}

\begin{abstract}
Premature loss of functional integrity of the nervous system in chronic renal failure (CRF) as a consequence of persistent biological activities of the general uremic milieu is almost identical to its structural and functional involution during the process of physiological ageing, but disproportionate and independent of chronological age. In the hyperuremic status of CRF (urea - carbamide), forced carbamylation, as a non-enzymatic post-translational modification (NEPTM) of proteins and amino acids, by changing their biological properties and decreasing proteolysis capacity, represents pathogenetic potential of intensified molecular ageing and accelerated, pathological involution. Physiological predisposition and the exposure of neuropathy before complications of other organs and organ systems in CRF, due to the simultaneous and mutually pathogenetically related uremic lesion and the tissue and vascular segment of the nervous system, direct interest towards proteomic analytical techniques of quantification of carbamylated products as biomarkers of uremic neurotoxicity. Hypothetically, identical to the already established applications of other NEPTM products in practice, they have the potential of clinical methodology in the evaluation of uremic neuropathy and its contribution to the general prediction, but also to the change of the conventional CRF classification. In addition, the identification and therapeutic control of the substrate of accelerated involution, responsible for the amplification of not only neurological but also general degenerative processes in $C R F$, is attractive in the context of the well-known attitude towards aging.

Keywords: chronic renal failure, neuropathy, carbamylation, pathological involution.
\end{abstract}

\section{SAŽETAK}

Prevremeni gubitak funkcionalnog integriteta nervnog sistema u hroničnoj bubrežnoj insuficijenciji (HBI) kao posledica perzistentnih bioloških aktivnosti opšteg uremijskog miljea, gotovo je identičan njegovoj strukturnoj i funkcionalnoj involuciji tokom procesa fiziološkog starenja, ali u disproporciji i nezavisan od hronološke dobi. U hiperuremijskom statusu HBI (urea - karbamid), forsirana karbamilacija, kao neenzimska postranslacijska modifikacija (NEPTM) proteina i aminokiselina, promenom njihovih bioloških svojstva i smanjenjem kapaciteta proteolize, predstavlja patogenetski potencijal intenziviranog molekularnog starenja i ubrzane, patološke involucije. Fiziološka predodređenost $i$ eksponiranost neuropatije ispred komplikacija drugih organa i organskih sistema u HBI, zbog istovremene i uzajamno patogenetski povezane uremijske lezije $i$ tkivnog $i$ vaskularnog segmenta nervnog sistema, usmerava interes ka proteomickim analitičkim tehnikama kvantifikacije karbamilovanih produkata kao biomarkerima uremijske neurotoksičnosti. Hipotetički, identično već etabliranim primenama ostalih produkata NEPTM u praksi, imaju potencijal kliničke metodologije u evaluaciji uremijske neuropatije i njenom doprinosu opštoj predikciji, ali i promeni konvencionalne klasifikacije HBI. Dodatno, identifikacija i terapijska kontrola supstrata ubrzane involucije, odgovornog za amplifikaciju ne samo neuroloških, več $i$ opštih degenerativnih procesa u HBI, atraktivna je u kontekstu opštepoznatog stava prema starenju.

Ključne reči: hronična bubrežna insuficijencija, neuropatija, karbamilacija, patološka involucija. 
and enzymatic and hormonal activity, reduces the proteolytic capacity of their degradation and induces irreversible changes in their biological properties (9).

\section{INTRODUCTION}

Complexity of cerebro-renal connections and influences in the pathogenesis of uremic neuropathy as a front-line clinical exponent of the effects of persistent biological activities of the uremic milieu on all organ systems in CRF, maintains the attention of the scientific and professional public: a large number of review papers summarize available data on nature, pathophysiology, clinical diversity and treatment of neurological complications in CRF (1-4). Decades of knowledge about the biological effects of uremic retention substances and the analysis of the toxic capacity of currently known organic uremic compounds are summarized in the latest review article (5). For 71 substances or groups of substances, adverse effects were found in the cardiovascular and hematological segment, metabolic bone disease in CRF, infection, thrombogenesis, inflammation, fibrosis as a factor in CRF progression, metabolic dysfunction, insulin resistance and neurotoxicity. A total of 15 compounds, experimentally proved to be neurotoxic, are present in each of three groups of conventionally agreed division of uremic toxins: a group of small water-soluble compounds (guanidines, ADMA, TMA, myo-inositol, polyamines), a group of protein-bound compounds (kinurenin, AGE, phenyl acetic acid, quinoline acid) and a group of medium molecules ( $\beta 2$-microglobulin, cystatin $\mathrm{C}$, ghrelin, neuropeptide $\mathrm{Y}$, methionine-enkephalin, parathyroid hormone). In the context of the multifactorial contribution of each of the above effects to the complex pathogenesis of uremic neuropathy, the number of indirectly neurotoxic substances is respectfully higher (6).

From this perspective, simultaneous presence of most uremic toxins in vivo, increasingly challenges the benefit of examining the specific effects of a single substance (or a group of substances) and justifies approaching the concept of combined, common mechanisms of pathogenesis of functional and structural damage at all the levels of the nervous system in CRF (7, 8). Literature especially emphasizes the negative contribution of the combination and mutual strengthening of vascular and nonvascular, i.e. tissue pathogenetic mechanisms in the development of uremic neuropathy as a clinical entity (Figure 1) $(7,8)$. The consequences of synchronized adverse effects of persistently present retention substances, originally of different biological activities, redirect research interests from individual inducers to universal pathological reactions in promoting the influence of the general harmfulness of the disturbed metabolic balance on all the structures of the nervous system. Among them are chemical reactions of non-enzymatic posttranslational modification (NEPTM) of proteins, especially glycation, oxidation (or combined glycoxidation, due to close connection), carbamylation, phosphorylation, nitration, citrullination and deamidation as natural biological regulators of protein interactions and transport. However, NEPTM using molecular conformations of proteins interferes with receptor recognition
In physiological circumstances, NEPTM changes in protein structure and function are the most significant for long half-life proteins and represent one of the mechanisms of gradual attenuation of functions and tissue degeneration in the process of physiological aging (10). In changed pathophysiological circumstances, increased activity and irreversibility of reactions of NEPTM of proteins of different biological properties and roles, increases the formation of their degradation products, the accumulation of which contributes to the development of complications (11). In the pathophysiological milieu of CRF, chemical reactions of NEPTM of proteins also form the basis for the development and manifestation of most chronic complications of CRF, including uremic neuropathy (12). The comparative similarity of neurological disorders in CRF with signs of ageing as a consequence of physiological structural and functional involution of the nervous system, through the functional decline and altered visual aspect, forms a specific social and overall medical identity and qualifies a patient with uremic neuropathy as biologically older comparing to his chronological age (10-12) (Figure 2). The premise of the metabolic genesis of forced ageing during CRF, with this association, represents an additional provocation for scientific verification and recognition of the messages and lessons that uremic neuropathy sends us, with probably many more that we did not recognize, although they possibly represent the basic starting point.

Complex sensitivity of the nervous system as a physiological indicator of general cumulative damage during CRF, raises questions about the validity of current retention markers and their kinetics and imposes the need to objectify the significance of initial and later registered neurophysiological alterations in uremia, through the redefinition of clinical and biochemical markers. The advance in the research evaluation of uremic neurotoxicity leads to a discussion of new approaches towards modifying existing diagnostic-therapeutic procedures into future useful and effective preventive and therapeutic concepts of its control and attenuation.

\section{THE ROLE OF CARBAMYLATION IN METABOLIC FRAMEWORK OF UREMIC NEUROPATHY}

So far, the greatest attention of researchers and clinicians has been attracted by glycation, the molecular transformation of proteins and lipoproteins which, by the process of binding carbonyl groups of sugars to protein amino groups and exposed to oxidative processes, become advanced glycation end products (AGEs). During life, the resulting AGEs accumulate in the tissues, participating in the process of physiological ageing. Increased or accelerated glycation in diabetes mellitus is responsible for most complications of this disease (13-15). Also, AGEs are proven protein-bound neurotoxic substances in the metabolic imbalance in CRF (6). 
However, in recent years, a large number of publications confirm the change in the focus of activity towards carbamylation - posttranslational modification of proteins caused by the non-enzymatic reaction of isocyanic acid and the addition of carbonyl groups $\left(-\mathrm{CONH}_{2}\right)$ to free $\alpha$-amino groups of amino acids and $\varepsilon$-amino groups of lysine. Isocyanic acid is formed by spontaneous equilibrium dissociation of urea cyanate or thiocyanate catabolism, mediated by myeloperoxidase (16). Basally, in the plasma of healthy individuals, it reaches a level of about $50 \mathrm{nmol} / 1$, while in patients with CRF, values of about $150 \mathrm{nmol} / \mathrm{l}$ are registered (5, 6). Carbamylation is therefore accelerated and intensified in uremia (Figure 2). Homocitrulline (HCit), the most characteristic carbamylation product that can be specifically quantified (17), is accumulated more intensely than carboxymethyl-lysine, one of the main glycation end products, showing a more significant role of carbamylation comparing to glycoxidation reactions in functional and structural degenerative processes. As a continuously active ageing factor in combination with other genetic and acquired factors (cell aging, shortening of telomeres, reduced proliferative capacity, individual mutations of mitochondrial DNA and inflammation), carbamylation gradually leads to structural tissue damage and a decline in the functions of the organism as a whole. In physiological circumstances with continuous NEPTM throughout life, the degree of accumulation of carbamylated forms of long half-life proteins as primary substrates (matrix proteins, such as type I collagen and elastin) correlates with the predisposition of non-regenerative tissue types and life expectancy of certain species of mammals, including humans (10-12).

During CRF, chronic hyperuricemia and forced carbamylation (urea - carbamide), by increased production of carbamylated proteins in plasma and all tissues, alter the interaction with inflammatory cells and sensitivity to proteolysis, leading to the aberrant tissue remodeling, the dysfunction of target organs and the occurrence of chronic complications (19). Uremic neuropathy is an unfavorable result of a specific predisposition for cumulative harmfulness of carbamylation of "non-renewable" resident (postmitotic) cells of the nervous system, with a close connection with the consequences of carbamylation of other nervous system structures, primarily the cerebral and peripheral microvascular segment (20). Therefore, from both the research and clinical point of view, uremic neuropathy is an important criterion for assessing the severity and prediction of CRF progression and outcome, but also a strong indicator and promoter of accelerated ageing of the whole organism (Figure 3).

Compared to other organs and organ systems, carbamylation role studies are predominantly focused on the cardiovascular system (myocardial remodeling, endothelial and autonomic dysfunction, accelerated atherogenesis, induction of arrhythmogenicity, etc.). Several clinical studies have established a correlation of carbamylated compounds with cardiovascular pathology and outcomes in subjects with CRF (2124). If the negative impact is observed through generalized consequences on the structure and function of the entire vascular network, carbamylation-mediated vascular pathology as a non-traditional risk factor only formally refers to cardiac sequelae (25): cerebrovascular network and vasa nervorum network represent a logical parallel and a need to convey constructive disquisitional conclusions about uremic vasculopathy and into the sphere of uremic neuropathy (26, 27). Carbamylated low-density lipoproteins (LDL) and highdensity lipoproteins (HDL) affect vascular cell changes relevant to atherogenesis (28-30) and endothelial recovery function $(31,32)$. Carbamylated products modulate inflammatory responses $(33,34)$ and stimulate thrombogenesis $(35-37)$. In addition to impaired mineral and bone metabolism and vascular calcification, they jointly contribute to accelerated generalized sclerosis in uremia: the blood vessels of adolescents with terminal, dialysis-dependent CRF are degeneratively altered as the blood vessels of people who are decades elder $(38,39)$ and baroreceptor calcifications affect the autonomic segment of vascular reactivity. Because of the proven pathological effects on the vascular endothelium of the local microcirculation of the peripheral nerves and the cerebrovascular segment, the increased carbamylation intensity during CRF $(40,41)$ is an important link in understanding the higher incidence and worse prognosis of cerebrovascular episodes in the population with CRF than in the control one of the same chronological age (42). The aspect of the second pathogenetic position, i.e. the consequence of carbamylation of non-vascular structures of the nervous system, has not been clinically evaluated so far.

In general, after diabetes, uremic is the second most common metabolic neuropathy. Neurotoxicity of AGE from one direction (6) and the resistance to insulin receptors modified by carbamylation from the other direction $(43,44)$, mutually reinforce the adverse reactions of NEPTM (45). Additionally, the reverse negative impact of intensified NEPTMs in diabetes and CRF is achieved by activating mesangial cells into a profibrogenic prototype, forcing further progression and severity of CRF $(46,47)$.

In literature and clinical practice, cognitive alteration has been designated as an introductory and nonspecific manifestation of neurological complications in CRF (48-51). High concentrations of toxins (up to 10 times higher in patients with CRF than in control groups) found in the regions of thalamus, mammary glands and cerebral cortex, anatomical substrates of cognition (7), link cognitive dysfunction to an enhanced neuronal apoptotic response as an effect of NEPTM reactions, induced by uremic toxins, and which defines it as an objectively highly sensitive first, i.e. early, clinical exponent of general and cumulative uremic toxicity (Figure 4). Made by direct toxic action or indirect mechanisms, lesions of the region - morphological substrates of cognition and/or dementia, represent the announcement of expected progression or the presence of greater and more serious damage in the nervous system itself, and further, at all the levels and throughout the body $(52,53)$.

Sensitivity of this region to the long-term accumulation of basal carbamylation products as a physiological process 
during life, allows us to understand the neurological complications associated with ageing (54). The parallel of cumulative degenerative tissue lesions in CRF is examined and proven cellular accumulation of damaged, poorly degraded proteins in the extracellular matrix of the skin, caused by long-term processes of basal oxidation and carbamylation during the physiological ageing process (15), but also in the brain tissue of patients with neurodegenerative diseases (Alzheimer's, Parkinson's and Creutzfeldt-Jakob disease), additionally and pathologically intensified reactions of citrullination, deamidation and phosphorylation (54).

\section{METABOLIC-OXIDATIVE SYNERGISM OF UREMIC NEUROPATHY}

In specific physiology and metabolism of the nervous system, the homeostatic imbalance of uremia has great potential for mutual NEPTM interactions of glycation, oxidation, and carbamylation. Particularly exposed is high sensitivity of nervous tissue to oxidative stress due to low oxidative capacity, in conditions of disturbed redox balance in CRF (55). Prooxidant uremia, as opposed to reduced protection by protective mechanisms, causes dominance and accumulation of reactive redox molecules, which is fatal to neurons as postmitotic cells (56): cell membrane damage because of the lipid peroxidation, NEPTM changes in protein structure and function due to oxidation and structural DNA damage, with the expression of neuroinflammation mediators (interleukin-1 $\beta$, interleukin-6, tumor necrosis factor- $\alpha$ (TNF$\alpha)$ ) in macrophage/macroglia polarization, the activation of astrocytes and infiltration of monocytes, lead to the acceleration of neurodegenerative processes and progression of neurological complications $(57,58)$. The oxidative inhibition of nerve fiber enzymes, required to maintain energy production for impulse conduction and axonal transport, but also the baroreceptors function, is additionally responsible for peripheral and autonomic neuropathy in CRF (59).

Under normal circumstances, the formation and reactions of free radicals are limited by the defense systems of exogenous and endogenous antioxidants. With the exception of the low molecular weight scavenger group, all other antioxidants are proteins: enzymes that directly remove oxidants (e.g. superoxide dismutase) or their precursors (e.g. peroxiredoxin, glutathione peroxidase, and catalase peroxides) and enzyme systems that repair damages (methionine sulfoxide reductases, disulfide reductases/zomerases, sulfiredoxins) or remove damaged material (e.g. proteasomes, lysosomes, proteases, phospholipases, DNA repair enzymes) (60). Some defense systems are subject to variations in activity (e.g. as a result of changes in transcription and/or translation, or direct damage) or are dependent on cofactors that can be easily depleted (carbamylated/oxidized). It is known that ageing leads to a general decrease in the activity of many enzymes, including those that are in the antioxidant group of scavengers, and that their decline can be accelerated by diseases, specifically $\mathrm{CRF}$, or external factors. Regardless of the duration of biological life and the primary site of action of enzymes (in plasma or tissues), the extent and number of short-term and long-term NEPTM changes in their biological properties as functional proteins in the uremic status, is an important way to weaken their role in antioxidant defense mechanisms and gradually, but progressively, leads to definitive tissue, neurodegenerative damage (21).

In $\mathrm{CRF}$, the increased genesis of isocyanic acid via thiocyanate catabolism mediated by myeloperoxidase (MPO) is not negligible, in addition to the dominant spontaneous dissociation of urea cyanates. Although MPO has a desirable negative effect on the extent of adaptive immune responses, it does not inhibit proinflammatory processes: any uncontrolled activation of MPO generates a wide range of oxidants, much more potent in the oxidation of biomolecules, which are biological markers of inflammatory and oxidative stress in several chronic diseases, such as rheumatoid arthritis, cardiovascular diseases, liver diseases, diabetes and malignancies (61). In neuropathology, elevated MPO levels have been reported in autoimmune diseases of the central nervous system and multiple sclerosis. In the chronic inflammatory status of CRF, an increase in MPO activity and forced carbamylation is also expected. Recent researches indicate that oxidative stress, associated with the activity of the MPO / $\mathrm{H}_{2} \mathrm{O}_{2}$ / thiocyanate system in CRF, contributes to greater tissue damage in a stroke, which is an indirect indicator of the predisposition of brain tissue, for its occurrence and outcomes in CRF (62).

On the other hand, cyanate, as a free radical in balance with urea, in the hyperuricemic status of CRF with its increased concentrations, has an isolated detrimental effect on the vascular endothelium: in vitro has been proven, depending on time and concentration, to inhibit NOS expression of coronary endothelial cells (it mediates on transcription levels and/or by decreased mRNA stability, but not by increased ubiquitin protease degradation), to increase the expression of the thrombogenic tissue factor and plasminogen activator inhibitors, which is a negative procoagulant contribution to the higher incidence of cerebrovascular events in patients with CRF $(7,8,63)$. Also, in vitro studies have confirmed that ammonia, another urea derivative formed by the action of intestinal bacterial urease and urea itself, lead to the changes in the expression of transmembrane proteins of narrow junction of intestinal epithelial cells and disruption of the integrity of the intestinal epithelial barrier in CRF, the entry of endotoxins from intestinal lumen into the bloodstream and the initiation of a systemic inflammatory response (64). A similar baneful influence of elevated concentrations of urea derivatives is manifested in the damage of the blood-brain barrier by triggering the oxido-inflammatory cascade. By activating the inflammatory and oxidative pathways on one hand, and inhibiting the antioxidant and cytoprotective system on the other hand, mediated by an increase in nuclear translocations of NF- $\mathrm{KB}$ and a reduction in nuclear translocations of Nrf2, they affect key target gene products - the markers of oxidative and myeloperoxidase reactions, the mediators of fibrosis and protein features of the endothelial narrow junction complex. Dissociation of disulfide bonds in extracellular domains of transmembrane proteins (occludin, claudin-5 and binding 
molecule (JAM)) or contraction of their intracellular domains via actin and myosin, lead to rapid endocytosis and degradation, so the degradation of these proteins leads to the erosion of cerebral capillary junction and damage of blood-brain barriers. This enables the entry from the systemic circulation of other retention uremic toxins and/or already formed mediators for further activation of NF- $\kappa \mathrm{B}$ in neuroinflammatory and degenerative processes of all structures of the nervous system (65).

Early and late effects of the influence of the prooxidative status of CRF on the resident cells of the nervous system, indicate an indirect pathogenetic potential of metabolically induced molecular conformations, i.e. carbamylation of protein structures of enzymes and receptors of endogenous antioxidants. Thus, they hypothetically allocate space for preventive-therapeutic slowing down or weakening of the neurotoxicity-mediated process. The question of the reality of clinical application of some of the stable products of the control of activity of the inflammatory-oxidative cascade in CRF remains open (66). The activity of MPO has a proven predictive and prognostic significance in cardiovascular and cerebrovascular pathology (62).

\section{THE ROLE OF CARBAMYLATION IN METABOLIC SHIFT DURING UREMIC NEUROPATHY}

The effects of urea derivatives, cyanide, ammonia and carbamylated compounds, in non-physiological circumstances of CRF, affect the biological properties of various molecules to a greater extent than their precursor, but by the mechanism of molecular aging which occurs and develops gradually and over a long period of time, even at lower serum urea concentrations, which have been considered clinically insignificant so far. The biological effects of urea derivatives in CRF (6) represent less intense but constant transformations and changes in tissue structures and functions of organs and organ systems in CRF in the direction of universal, generalized acceleration of their physiological involution, disorders and chronic complications, including neurological ones (67). In relation to the test results and the proven lack of correlation of current serum urea concentrations with long-term outcomes (controlled randomized HEMO and ADME studies) (68-70), an important difference is the chronic, gradual, progressive and cumulative biological impact of carbamylated compounds, its derivatives: the initial changes to irreversible degenerative damage depend on the time of exposure and on the levels of serum exceedances of optimal values in all stages of CRF, and not only dialysis-dependent (71). In such an approach, the current serum urea values as criteria for the retention or adequacy of dialysis are in fact only kinetic parameters, without objectifying the real effect (72).

New scientific and clinical facts are arguably changing the attitude about the neurotoxic inertness of urea towards its long-term, cumulative toxicity by means of its derivatives, predominantly exposed through the process of carbamylation (or carbonylation) of building and functional proteins of all levels of the nervous system. The carbamylated products in the blood, consentaneous with the organ-specific cumulative tissue lesion, i.e. its clinical presentation of asymptomatic or symptomatic central, peripheral or autonomic uremic neuropathy, standardized and scored in the algorithm, can, as an objective measure, eliminate individual variations in the difference between real biological and chronological age. Finally, perhaps most provocatively, they hypothetically have the capacity of practical clinical methodology, i.e. the use of biochemical-clinical indicators of uremic neuropathy as an extant tool in monitoring and controlling the general cumulative toxic effect of uremia on the whole organism during CRF, pre-terminal and terminal, dialysis-dependent stage (19). The parallel to this approach is the affirmed clinical place and the importance of glycosylated hemoglobin, which potentiates the cumulative effect of all glycemic values in the control of chronic complications of diabetes mellitus, including diabetic neuropathy, related to the currently registered serum level. The awareness of the long-term quality of glycoregulation is a realistic parameter of the quality of the control of progression and delay in the occurrence of complications of diabetes. The determination of anti-citrulline antibodies in rheumatoid arthritis is another confirmation of the relevance of NEPTM of proteins as biomarker substrates of specific disorders in clinical practice.

Since carbamylation is both a cumulative and time-dependent reaction, so far examined changes in the biological properties of carbamylated compounds, such as LDL, albumin, erythropoietin or homocitrulline (already tested and proven measure of quantification of systemic carbamylation) in cardiovascular pathology (73-76), are considered for an objective assessment of the harmful effects of long-term exposure of the nervous system to uremic toxins (6), as well as a replacement for the diagnostic "surrogate" (the reduction of glomerular filtration and creatinine clearance) in the assessment of renal insufficiency. Carbamylated products, as selected (agreed) biochemical markers, reinforce the idea that urea has the potential of a toxin that mediates its neurotoxicity by carbamylation (16). Two main approaches can be used to determine the degree of protein carbamylation: the quantification of a specific carbamylated protein (in this case this protein has a direct connection with a precise pathological substrate) or the estimation of the total level of carbamylation by quantification of binding protein HC. Several analytical methods, based on different principles, have been developed to quantify carbamylated products in the blood, ranging from more conventional, colorimetric and immunological tests to the most sophisticated methods, such as high performance liquid chromatography (HPLC), combined by mass spectrometry (HPLC-MS / MS).

Carbamylated hemoglobin $(\mathrm{cHb})$ was initially identified as a controversial analytical interference in the measurement of glycosylated hemoglobin (HbA1c) by ion-exchange chromatography. Carbamylated hemoglobin is mainly the result of the covalent binding of isocyanic acid to the $\mathrm{N}$-terminal valine residue of globin b chain (77), and the level is 
measured by liquid chromatography together with ultraviolet detection of hydantoin derivative $\mathrm{N}$-carbamyl valine, obtained by hydrolysis. The concentration of $\mathrm{cHb}$ is generally expressed in micrograms of valine hydantoin $(\mathrm{VH})$ per gram of total hemoglobin $(\mathrm{mgVH} / \mathrm{gHb})$. Its value ranges between 27 and $40 \mathrm{mgVH} / \mathrm{gHb}$ in healthy individuals, but exceeds up to five times the optimal level in CRF $(78,79)$. Thus, $\mathrm{cHb}$ levels have the potential to be a useful biomarker of cumulative neurotoxicity in $\mathrm{CRF}$, as $\mathrm{HbA} 1 \mathrm{C}$ is in diabetes.

\section{UREMIC NEUROPATHY - CLINICAL MARKER FOR MONITORING THE PROGRESSION OF CRF CONTROL?}

Renal anemia and metabolic bone disease are routine and mandatory segments of periodic evaluation in the monitoring of patients in the third, fourth and fifth stage of renal failure, while neurological disorders are included only as symptomatic or functionally limiting, which is the reason for unreliable data on the real prevalence of uremic neuropathy during CRF (1-4).

Unfortunately, asymptomatic or nonspecific and discrete, initially often transient cognition disorders, autonomic, sensormotor and muscle peripheral latent dysfunction and transient ischemic episodes, which represent early clinical exponents of the present general uremic damage to all organs and organ systems are not in the focus of clinicians. The identification and objective assessment of neurological disorders at this stage, regardless of the presence or absence of symptoms, a range of known clinical diagnostic tests / examinations in neurology, which are established, but selectively and individually applied, is not yet standardized or mandatory in clinical monitoring of patients with CRF (80-82). Based on the data on the prevalence of neuropathy correlated with renal function in non-dialysis phases of CRF, the need for recording during routine visits to a nephrologist (without a certain attitude towards asymptomatic forms), ranking, and active therapeutic treatment with the aim of slowing the progression is emphasized. Measurement of neuro-electrophysiological activity (ECG, EEG, EMG) and updating of cerebrovascular status (blood pressure variations, a Doppler of blood vessels, cardiac kinetics) are methods of assessing the severity of functional deficits, mostly already present symptomatic forms of the clinical expression of histo-morphological lesions in autonomic, central and peripheral segments of the nervous system. Limited to the fact that most of the available information on neuropathy comes from studies of subjects with terminal, dialysis-dependent $\mathrm{CRF}$, the current guidelines suggest the presence and extent of uremic neuropathy in predialysis stadium of CRF as a criterion for initiating active dialysis detoxification, and later for correcting its efficacy $(83,84)$.

On the other hand, due to individual variability, the invalidity of conventional standard neurophysiological indices of neuropathy in monitoring the progression of CRF or the adequacy of depuration treatments of the terminal, dialysis-dependent stage was highlighted. The current guidelines suggest and emphasize the need for a more precise and specific assessment of the neuro-renal relationship, i.e. the detection and severity of clinical expression of the subjective and objective parameters of uremic neuropathy. The extension of the basic package of biochemical analyses to carbamylated products as parameters - indicators of cumulative metabolic damage in CRF, has the capacity to respond to the missing segments in the mosaic of all non-traditional factors (19). With the quantification of selected metabolites of interest as new biomarkers, the application of reliable complementary clinical tests, through modified formal neuro-psychological evaluation and modified assessment of overall neuropathy, would represent a triad of derived targeted methods with exclusive diagnostic potential (Table 1).

The higher prevalence of cognitive alteration and dementia in patients with CRF (48-51), comparing to the general population, independent and unmatched with age, although widely studied and proven correlations with many factors of uremic status, is still relatively neglected in clinical guides and practice (85). The most sensitive region of the central nervous system which is defined, and predisposed place of the first, initial neuro-, but also the cumulative general toxic action of various retention substances, mediated by oxidative stress and carbamylation, as NEPTM in the combined pathophysiological influence, create space for systematized periodicity of additional response, both in advanced dialysis-independent stages and terminal stages of CRF, while the detected initial changes are local, corrective, and reversible. In the research domain, a battery of neuropsychological tests of formal neuro-psychological detection of mild cognitive impairment as an entity, is mainly conducted in correlation studies with other harmful variables of uremic status (e.g. inflammation) (48-51). This review is seen as a clinical expression potential that objectifies and measures the intensity of metabolically generated acceleration of uremic neurotoxic (and general) lesions, with the aim of inducing changes in the pharmacological and therapeutic concept to preserve functional and structural integrity, to slow involution, i.e. to delay accelerated ageing, and also to maintain the quality of life in patients with CRF (86). In this context, a modified formal neuropsychological evaluation (Clock Drawing Test, Mini Mental Test and Clinical Dementia Scale) to assess deficits in various areas of cognitive impairment (memory, executive function, attention, concentration, perception and / or language skills) and dementia (cognitive dysfunction and behavioral disorders), implies structural testing with a definite earlier "first treatment" and regularly adopted dynamics during the duration of CRF (87-89).

Modified Total Neuropathy Score (TNS) assessment, confirmed in diabetic and chemotherapy-induced neuropathy (90) and, in accordance with the consensus statement of the American Academy of Neurology for the assessment of neuropathy in research, includes symptoms, signs and electrophysiological findings of nerve conduction examination (sensory amplitudes of the tibial and sural nerve). Combined into a structured neurological examination questionnaire, they show the severity of neuropathy and can be assessed on a 
five-level scale. TNS includes the amplitude of the sural nerve, which is among the most sensitive neuroconductive parameters for detecting neuropathy (91). An additional assessment tool, the Neuropathic Symptom Score (NSS) is a validated measure designed for diabetic peripheral neuropathy and assesses only the symptoms of neuropathy, and is also used in the HD population $(92,93)$. The questionnaire identifies the presence or absence of symptoms in three categories and assigns one point for each symptom that is present (four motor, three negative and two positive sensors). This idea of phase assessment, i.e. the degree of clinical expression of neuropathy by combining the results of NSS, the results of nerve conduction studies and the presence or absence of "disabling" neuropathic symptoms (i.e. sensory disturbances) was taken from a recently completed FINESSE study, the largest and longest reported randomized trial of the effects of convective dialysis to neurophysiological and clinical outcomes with the aim of reducing the frequency and severity of uremic neuropathy and improving the understanding of its nature (94).

Due to the fact that autonomic dysfunction occurs in early stages of CRF, and manifests itself in more than $50 \%$ of patients on hemodialysis, and that the size of sympathetic dominance corresponds to the severity of renal failure, a modified assessment of total neuropathy in CRF requires updating the autonomic segment (95). A structured questionnaire of periodic evaluation of uremic neuropathy should include routine clinical assessment of papillary, vascular and cardiac reflexes (identification of heart rate and blood pressure variability in relation to the respiratory cycle, predisposition to intradialysis hypotension, postural changes in blood pressure and the effect of manipulation by Valsalva maneuver with a potential) of indirect identification and delineation of integrated contribution of uremic autonomic neuropathy to increased cardiovascular morbidity and mortality in CRF (96). With detection of presence or absence of other known clinical exponents of autonomic dysfunction in CRF (impotence, dysfunction of gastric and bladder motility, sweating disorder), pathophysiological structural and functional insufficiency is rounded, conditioned by metabolic acceleration of the nervous system involution, as biologically older in relation to his chronological age, with a direct impact on the social and overall medical profile of patients with uremic neuropathy (Table 1).

\section{UREMIC NEUROPATHY - THERAPY AND PERSPECTIVE}

Prevention of the rise of serum urea levels as a precursor and starting substrate of chronic action of its derivatives, but also the changes in the concept of time (onset and duration) and the way of elimination of already present persistently elevated serum urea concentrations, all together represent the models of causal treatment of direct and indirect systemic neurotoxicity. Standardized and periodic clinical-biochemical monitoring of uremic neuropathy can methodologically follow responses to therapeutic treatments for slowing degenerative changes, as the basis for accelerated ageing in all stages of $\mathrm{CRF}$.

Option of controlling serum urea levels includes dietary reduction of urea production as a direct neurotoxin by the hypoprotein nutrition, inhibition of absorption at the intestinal mucosa level using oral adsorbent AST-120 (kremezin; Kureha Chemical, Japan) (97), correction of intestinal dysbiosis (98), use of unabsorbable polyethylene glycol solution (enteral depuration) (99). Clinically more delicate ways are the attenuation of harmful mechanisms of action or blocking of their direct actions at the level of cell membrane receptors, and the stimulation of antioxidant and cytoprotective mechanisms (97). An innovative approach to controlling the carbamylation of biomolecules by the effect of supplementation with specific amino acids, based on the fact that free amino acids are a potential means of removing reactive isocyanate, has shown a promising role in eliminating or reducing carbamylation of amino acids or proteins (glycylglycine supplemented in excess, with taurine, the most abundant intracellular amine capable of reducing carbamylation of albumin by up to $64 \%$ in vitro). Affinity of cyanates for $\alpha$-amino groups on free amino acids is higher than lysine side chains on proteins, and thus can act as a natural means of removing carbamylation. In addition, some vitamins such as ascorbic acid, $\alpha$-tocopherol and lycopene have also been found to help reduce LDL of carbamylation in vitro (100-101).

In terminal renal failure, dialysis methods of extracorporeal depuration can increase the elimination of uremic toxins from the body. Technological innovations of membranes and modulation of physical principles of elimination versus severity of clinical manifestations of uremic neuropathy are the focus of researchers and clinicians (102) because dialysis treatments, due to intermittency and technical limitations, have selective and incomplete therapeutic effects, especially in people with long-term CRF and resulting irreversible damage to the nervous system (103). Earlier kidney transplantation, i.e. the replacement with a native organ, in younger, preadult patients, leads to a significant improvement in the initial forms of uremic neuropathy, emphasizing the importance of early treatment of dialysis elimination, in the absence of or giving up on the precisely defined most potent individual neurotoxin, and with the idea of control of obviously timeand dose-dependent cumulative neurological and general damage (104).

At present, current attitudes narrow the causality of uremic neuropathy to general pathogenetic mechanisms and combined effect of uremic toxins, which remain in the body as a predisposition for neurological manifestations due to the damaged physiological functions of the kidneys: groups of medium molecules and groups of protein-related compounds. This assumption, which correlates with the widespread use of high-flow dialysis membranes (defined by higher clearance of medium molecules), is supported by a decrease in the incidence of b2-microglobulin amyloidosis and a diminution of severity of uremic neuropathy (94). Despite these associations, the evidence for the medium molecule 
hypothesis has been insufficient so far. Peritoneal dialysis modality is associated with better neurophysiological parameters in relation to hemodialysis, but not in relation to highflow dialysis. The differences are attributed to the higher clearance of the middle molecule (and protein carbamylation products?) of the peritoneal membrane and the continuity of elimination provided by the peritoneal modality in relation to the intermittency of hemodialysis procedures, which all are not negligible factors for dialysis treatment (105).

Therefore, in the context growing interest in carbamylated products as interesting factors of risk and prognosis, the development of appropriate analytical methods for biomarker identification has the perspective of useful tools for therapeutic management of uremic neuropathy in all stages of CRF.

\section{CONCLUSION}

Uremic neuropathy through the premise of metabolic genesis of neurodegeneration by forced carbamylation mechanism, justify the statement that the one who has CRF is ill and ages rapidly. Innovative approaches to the control of uremic neuropathy perspectively represent not only the control of CRF progression, but also the slowing down of the generalized ageing process of the organism as a whole.

Most of animal and clinical studies do not automatically dispel the idea that urea is inert, but that the potential of the uremic toxin is predominantly realized by carbamylation at the systemic level. By isolating the cumulative lesion of the nervous system carbamylated products are becoming not just an interesting risk and prognostic factors, but also useful tools for therapeutic interventions.

The change of conventional quantification and the need for standardization of neurological complications using carbamylated protein substrates as new biomarkers of cumulative uremic toxicity, with the revaluation of the clinical importance of already established procedures for updating the functional presentation of neurological complications of $\mathrm{CRF}$, represent a more objective assessment of neurophysiological homeostasis imbalance.

Selected biochemical markers require new prospective randomized studies, in order to check the potential of urea as a uremic toxin that mediates its toxicity by carbamylation, complementary to an organ-specific cumulative tissue lesion, i.e. its clinical presentation of asymptomatic or symptomatic central, peripheral or autonomic uremic neuropathy.

\section{LITERATURE}

1. Uremic neuropathy: an overview of the current literature REVIEW ARTICLE Rev. Assoc. Med. Bras. 2019 Feb;65(2):281-286.
2. Chillon J.M., Massy Z.A., Stengel B. Neurological complications in chronic kidney disease patients. Nephrol. Dial. Transplant. 2016 Oct;31(10):1606-14.

3. Lau WL, Huisa BN, Fisher M.The CerebrovascularChronic Kidney Disease Connection: Perspectives and Mechanisms.Transl Stroke Res. 2017 Feb;8(1):67-76.

4. Lakshman SG, Ravikumar P, Kar G, Das D, Bhattacharjee K, Bhattacharjee P. A Comparative Study of Neurological Complications in Chronic Kidney Disease with Special Reference to its Stages and Haemodialysis Status. J Clin Diagn Res. 2016;10(12):OC01-OC04.

5. Vanholder R. et al. Review Biochemical and Clinical Impact of Organic Uremic Retention Solutes: A Comprehensive Update. Toxins. 2018; 10(1), 33.

6. Lisowska-Myjak B. Uremic Toxins and Their Effects on Multiple Organ Systems. Nephron Clin Pract. 2014; 128:303-311.

7. Assem M, Lando M,Grissi M, Kamel S, Massy ZA, Chillon J, Hénaut L. The Impact of Uremic Toxins on Cerebrovascular and Cognitive Disorders. Toxins. 2018; 10(7): 303.

8. Vanholder R,Baurmeister U, Brunet P, Cohen G, Glorieux $\mathrm{G}$, Jankowski J. A bench to bedside view of uremic toxins.J Am Soc Nephrol. 2008; 19: 863-870.

9. Gillery P, Jaisson S. Usefulness of non-enzymatic posttranslational modification derived products (PTMDPs) as biomarkers of chronic diseases, J. Proteomics. 2013; 228-238. 2013 Oct 30;92:228-38.

10. Jaisson S, Gillery P. Evaluation of nonenzymatic posttranslational modificationderived products as biomarkers of molecular aging of proteins, Clin. Chem.56, 2010; 1401-1412. 2010 Sep;56(9):1401-12.

11. S. Jaisson, A. Desmons, L. Gorisse, P. Gillery, Protein molecular aging: which role in physiopathology? Med. Sci. 2017 Feb;33(2):176-182.

12. P. Gillery, S. Jaisson, Post-translational modification derived products (PTMDPs): toxins in chronic diseases? Clin. Chem. Lab. Med. 2014 Jan 1;52(1):33-8.

13. D.R. Sell, M.A. Lane, W.A. Johnson, E.J. Masoro, O.B. Mock, K.M. Reiser, J.F. Fogarty, R.G. Cutler, D.K. Ingram, G.S. Roth, V.M. Monnier, Longevity and the genetic determination of collagen glycoxidation kinetics in mammalian senescence, Proc. Natl. Acad. Sci. U. S. A. 1996 Jan 9;93(1):485-90.

14. R. Meerwaldt, J.W. Hartog, R. Graaff, R.J. Huisman, T.P. Links, N.C. den Hollander, S.R. Thorpe, J.W. Baynes, G. Navis, R.O. Gans, A.J. Smit, Skin autofluorescence, a measure of cumulative metabolic stress and advanced glycation end products, predicts mortality in hemodialysis patients, J. Am. Soc. Nephrol. 2005 Dec;16(12):3687-93.

15. R.P. van Waateringe, S.N. Slagter, A.P. van Beek, M.M. van der Klauw, J.V. van Vliet-Ostaptchouk, R. Graaff, A.D. Paterson, H.L. Lutgers, B.H.R. Wolffenbuttel, Skin autofluorescence, a non-invasive biomarker for advanced glycation end products, is associated with the metabolic syndrome and its individual components, Diabetol. Metab. Syndr. 2017 May 30;9:42. 
16. Jaisson, S., Pietrement, C., \& Gillery, P. Protein Carbamylation: Chemistry, Pathophysiological Involvement, and Biomarkers. Advances in Clinical Chemistry..2018;84:1-38.

17. Jaisson, I. Kazes, A. Desmons, F. Fadel, J.B. Oudart, I.C. Santos-Weiss, H. Millart, F. Toure, P. Rieu, P. Gillery, Homocitrulline as marker of protein carbamylation in hemodialyzed patients, Clin. Chim. Acta . 2016 Sep 1;460:5-10.

18. L. Gorisse, C. Pietrement, V. Vuiblet, C.E. Schmelzer, M. Kohler, L. Duca, L. Debelle, P. Fornes, S. Jaisson, P. Gillery, Protein carbamylation is a hallmark of aging, Proc. Natl. Acad. Sci..PNAS February 2, 2016; 113 (5) 1191-1196

19. Delanghe, S.; Delanghe, J.R.; Speeckaert, R.; Van Biesen, W.; Speeckaert, M.M. Mechanisms and consequences of carbamoylation. Nat. Rev. Nephrol. 2017 Sep;13(9):580-593.

20. S. Kalim, C.A. Trottier, J.B. Wenger, J. Wibecan, R. Ahmed, E. Ankers, S.A. Karumanchi, R. Thadhani, A.H. Berg, Longitudinal changes in protein carbamylation and mortality risk after initiation of hemodialysis, Clin. J. Am. Soc. Nephrol. 2016 Oct 7;11(10):1809-1816.

21. E.O. Apostolov, D. Ray, A.V. Savenka, S.V. Shah, A.G. Basnakian, Chronic uremia stimulates LDL carbamylation and atherosclerosis, J. Am. Soc. Nephrol. 2010 Nov; 21(11): 1852-1857.

22. E.O. Apostolov, A.G. Basnakian, E. Ok, S.V. Shah, Carbamylated low-density lipoprotein: nontraditional risk factor for cardiovascular events in patients with chronic kidney disease, J. Ren. Nutr. 2012 Jan;22(1):134-8.

23. W.H. Tang, K. Shrestha, Z. Wang, A.G. Borowski, R.W. Troughton, A.L. Klein, S.L. Hazen, Protein carbamylation in chronic systolic heart failure: relationship with renal impairment and adverse long-term outcomes, J. Card. Fail. 2013 Apr;19(4):219-24.

24. S. Jaisson, M. Kerkeni, I.C. Santos-Weiss, F. Addad, M. Hammami, P. Gillery, Increased serum homocitrulline concentrations are associated with the severity of coronary artery disease, Clin. Chem. Lab. Med. 2015 Jan;53(1):103-10.

25. Mogi M, Horiuchi M. Clinical interaction between brain and kidney in small vessel disease, Cardiol Res Prac. 2011; 2011:306189.

26. Toyoda K. Cerebral small vessel disease and chronic kidney disease. J Stroke. 2015;17(1):31-7.

27. Seliger SL, Sarnak MJ. Subclinical vascular disease of the brain in dialysis patients. Am J Kidney Dis. 2007;50(1):8-10. Plus referenca broj 79 na strani 13

28. E.O. Apostolov, D. Ray, A.V. Savenka, S.V. Shah, A.G. Basnakian, Chronic uremia stimulates LDL carbamylation and atherosclerosis, J. Am. Soc. Nephrol. 2010 Nov;21(11):1852-7.

29. E.O. Apostolov, A.G. Basnakian, E. Ok, S.V. Shah, Carbamylated low-density lipoprotein: nontraditional risk factor for cardiovascular events in patients with chronic kidney disease, J. Ren. Nutr. 2012 Jan;22(1):134-8.

30. M. Holzer, M. Gauster, T. Pfeifer, C. Wadsack, G. Fauler, P. Stiegler, H. Koefeler, E. Beubler, R.
Schuligoi, A. Heinemann, G. Marsche, Protein carbamylation renders high-density lipoprotein dysfunctional,Antioxid. Redox Signal.2011 Jun 15;14(12):2337-46

31. Speer, F.O. Owala, E.W. Holy, S. Zewinger, F.L. Frenzel, B.E. Stahli, M. Razavi, S. Triem, H. Cvija, L. Rohrer, S. Seiler, G.H. Heine, V. Jankowski, J. Jankowski, G.G. Camici, A. Akhmedov, D. Fliser, T.F. Luscher, F.C. Tanner, Carbamylated low-density lipoprotein induces endothelial dysfunction, Eur. Heart J. 2014 Nov 14;35(43):3021-32.

32. J. Carracedo, A. Merino, C. Briceno, S. Soriano, P. Buendia, L. Calleros, M. Rodriguez, A. Martin-Malo, P. Aljama, R. Ramirez, Carbamylated low-density lipoprotein induces oxidative stress and accelerated senescence in human endothelial progenitor cells, FASEB J. 2011 Apr;25(4):1314-22.

33. Pieniazek, K. Gwozdzinski, Carbamylation and oxidation of proteins lead to apoptotic death of lymphocytes, Chem. Biol. Interact. 2017 May 25;270:24-32.

34. Koro, A. Hellvard, N. Delaleu, V. Binder, C. Scavenius, B. Bergum, I. Glowczyk, H.M. Roberts, I.L. Chapple, M.M. Grant, M. Rapala-Kozik, K. Klaga, J.J. Enghild, J. Potempa, P. Mydel, Carbamylated Il-37 as a modulator of the immune response, Innate Immun. 2016 Apr; 22(3): 218-229.

35. Koro, E. Bielecka, A. Dahl-Knudsen, J.J. Enghild, C. Scavenius, J.G. Brun, V. Binder, A. Hellvard, B. Bergum, R. Jonsson, J. Potempa, A.M. Blom, P. Mydel, Carbamylation of immunoglobulin abrogates activation of the classical complement pathway, Eur. J. Immunol.2014 Nov;44(11):3403-12.

36. E.W. Holy, A. Akhmedov, T. Speer, G.G. Camici, S. Zewinger, N. Bonetti, J.H. Beer, T.F. Luscher, F.C. Tanner, Carbamylated low-density lipoproteins induce a prothrombotic state via LOX-1: impact on arterial thrombus formation in vivo, J. Am. Coll. Cardiol. 2016 Oct 11;68(15):1664-1676.

37. V. Binder, B. Bergum, S. Jaisson, P. Gillery, C. Scavenius, E. Spriet, A.K. Nyhaug, H.M. Roberts, I.L.C. Chapple, A. Hellvard, N. Delaleu, P. Mydel, Impact of fibrinogen carbamylation on fibrin clot formation and stability, Thromb. Haemost. 2017 May 8; 117(5): 899910.

38. Vogels SC, Emmelot-Vonk MH, Verhaar HJ, Koek HL. The association of chronic kidney disease with brain lesions on MRI or CT: a systematic review. Maturitas. 2012;71(4):331-6.

39. Moodalbail DG, Reiser KA, Detre JA, Schultz RT, Herrington JD, Davatzikos $\mathrm{C}$, et al. Systematic review of structural and functional neuroimaging findings in children and adults with CKD. Clin J Am Soc Nephrol CJASN. 2013; 8(8):1429-48.

40. Wetmore JB, Phadnis MA, Ellerbeck EF, Shireman TI, Rigler SK, Mahnken JD. Relationship between stroke and mortality in dialysis patients. Clin J Am Soc Nephrol. 2015; 10(1):80-9. 64.

41. Dad T, Weiner DE. Stroke and chronic kidney disease: Epidemiology, pathogenesis, and management across 
kidney disease stages. Semin Nephrol. 2015; 35: 311322.

42. Koeth, R.A.; Kalantar-Zadeh, K.; Wang, Z.; Fu, X.; Tang, W.H.; Hazen, S.L. Protein carbamylation predicts mortality in ESRD. J. Am. Soc. Nephrol. JASN. 2013 Apr 30; 24(5): 853-861.

43. D’Apolito, M.; Du, X.; Zong, H.; Catucci, A.; Maiuri, L.; Trivisano, T.; Pettoello-Mantovani, M.; Campanozzi, A.; Raia, V.; Pessin, J.E.; et al. Urea-induced ros generation causes insulin resistance in mice with chronic renal failure. J. Clin. Investig. 2010 Jan;120(1):203-13

44. Koppe, L.; Nyam, E.; Vivot, K.; Manning Fox, J.E.; Dai, X.Q.; Nguyen, B.N.; Trudel, D.; Attane, C.; Moulle, V.S.; MacDonald, P.E.; et al. Urea impairs beta cell glycolysis and insulin secretion in chronic kidney disease. J. Clin. Investig. 2016; 126(9): 3598-3612.

45. L. Gross, G. Piecha, A. Bierhaus, W. Hanke, T. Henle, P. Schirmacher, E. Ritz, Glycated and carbamylated albumin are more "nephrotoxic" than unmodified albumin in the amphibian kidney, Am. J. Physiol. Renal Physiol. 301: 2011;F476-485.

46. L.M. Kraus, L. Gaber, C.R. Handorf, H.P. Marti, A.P. Kraus Jr., Carbamoylation of glomerular and tubular proteins in patients with kidney failure: a potential mechanism of ongoing renal damage, Swiss Med. Wkly. 2001 Mar 24;131(11-12):139-4.

47. M. Shaykh, A.A. Pegoraro, W. Mo, J.A. Arruda, G. Dunea, A.K. Singh, Carbamylated proteins activate glomerular mesangial cells and stimulate collagen deposition, J. Lab. Clin. Med. 1999;;133(3):302-8.

48. Watanabe K, Watanabe T, Nakayama M. Cerebro-renal interactions: impact of uremic toxins on cognitive function. Neurotoxicology. 2014;44:184-93.

49. Gaxatte C, Daroux M, Bloch J, Puisieux F, Deramecourt $\mathrm{V}$, Boulanger E. Cognitive impairment and chronic kidney disease: which links? Nephrol Ther. 2011;7(1):10-7.

50. Kurella Tamura M, Yaffe K. Dementia and cognitive impairment in ESRD: diagnostic and therapeutic strategies. Kidney Int. 2011;79(1):14-22.

51. Etgen T. Kidney disease as a determinant of cognitive decline and dementia. Alzheimer's Res Ther. 2015;7(1):29.

52. Murray AM. Cognitive impairment in the aging dialysis and chronic kidney disease populations: an occult burden. Adv Chronic Kidney Dis. 2008;15(2):123-32.

53. Bugnicourt J-M, Godefroy O, Chillon J-M, Choukroun G, Massy ZA. Cognitive disorders and dementia in CKD: the neglected kidney-brain axis. J Am Soc Nephrol. 2013;24(3):353-63.

54. Mormino EC, Papp KV, Rentz DM, Donohue MC, Amariglio R, Quiroz YT et al .Early and late change on the preclinical Alzheimer's cognitive composite in clinically normal older individuals with elevated amyloid $\beta$. Alzheimers Dement. 2017; 13:1004-1012

55. Locatelli F, Canaud B, Eckardt KU, Stenvinkel P, Wanner C, Zoccali C. Oxidative stress in end-stage renal disease: an emerging threat to patient outcome. Nephrol Dial Transplant. 2003;18(7):1272-80.
56. Kim G.H., Kim J.E., Rhie S.J., Yoon S. The Role of Oxidative Stress in Neurodegenerative Diseases.Exp Neurobiol. 2015 Dec; 24(4): 325-340.

57. Filiopoulos V, Hadjiyannakos D, Takouli L, Metaxaki P, Sideris V, Vlassopoulos D. Inflammation and oxidative stress in end-stage renal disease patients treated with hemodialysis or peritoneal dialysis. Int $\mathrm{J}$ Artif Organs. 2009;32(12):872-82.

58. Frank-Cannon T.C., Alto L.T., McAlpine F.E., Tansey M.G. Does neuroinflammation fan the flame in neurodegenerative diseases? Mol. Neurodegener. 2009;4:47.

59. Hsieh H.L., Yang C.M. Role of redox signaling in neuroinflammation and neurodegenerative diseases. BioMed Res. Int. 2013;2013:18.

60. Davies. M.J. Protein oxidation and peroxidationBiochemJ. 2016 Apr 1; 473(Pt 7): 805-825.

61. S. Sirpal, Myeloperoxidase-mediated lipoprotein carbamylation as a mechanistic pathway for atherosclerotic vascular disease, Clin. Sci. (Lond.) 116, 2009: 681-695.

62. Yu G., Liang Y., Zheng S., Zhang H. Inhibition of myeloperoxidase by n-acetyl lysyltyrosylcysteine amide reduces oxidative stress-mediated inflammation, neuronal damage, and neural stem cell injury in a murine model of stroke. J. Pharmacol. Exp. Ther. 2018;364:311322.

63. Allen C.L., Bayraktutan U. Oxidative stress and its role in the pathogenesis of ischaemic stroke. Int. J. Stroke. 2009;4:461-470.

64. Vaziri, N.D.; Yuan, J.; Norris, K. Role of urea in intestinal barrier dysfunction and disruption of epithelial tight junction in chronic kidney disease. Am. J. Nephrol. 2013;37(1):1-6.

65. Jing W, Jabbari B, Vaziri ND. Uremia induces upregulation of cerebral tissue oxidative/inflammatory cascade, down-regulation of $\mathrm{Nrf} 2$ pathway and disruption of blood brain barrier Am J Transl Res. 2018; 10(7): 21372147.

66. Davis S. M, Pennypacker K. R. . Targeting Antioxidant Enzyme Expression as a Therapeutic Strategy for Ischemic Stroke.Neurochem Int. 2017; 107: 23-32.

67. Eknoyan, G.; Beck, G.J.; Cheung, A.K.; Daugirdas, J.T.; Greene, T.; Kusek, J.W.; Allon, M.; Bailey, J.; Delmez, J.A.; Depner, T.A.; et al. Effect of dialysis dose and membrane flux in maintenance hemodialysis. N Engl J Med. 2002 Dec 19;347(25):2010-9.

68. Handley RR, Reid SJ, Brauning R, Maclean P, Mears ER, Fourie I, Patassini S, Cooper GJS, Rudiger SR, McLaughlan CJ, Verma PJ, Gusella JF, MacDonald ME, Waldvogel HJ, Bawden CS, Faull RLM, Snell RG. Brain urea increase is an early Huntington's disease pathogenic event observed in a prodromal transgenic sheep model and HD cases. Proc Natl Acad Sci U S A. 2017 Dec 26;114(52):E11293-E11302.

69. Meijers, B.; Vanholder, R. Hemo revisited: Why kt/vurea only tells part of the story. J. Am. Soc. Nephrol. JASN . 2016 Nov;27(11):3235-3237.

70. Meyer, T.W.; Sirich, T.L.; Fong, K.D.; Plummer, N.S.; Shafi, T.; Hwang, S.; Banerjee, T.; Zhu, Y.; Powe, N.R.; Hai, X.; et al. Kt/vurea and nonurea small solute levels 
in the hemodialysis study. J. Am. Soc. Nephrol. JASN 2016 Nov; 27 (11) 3469-3478.

71. M. T. Velasquez, A. Ramezani and D. S. Raj. Urea and protein carbamylation in ESRD: surrogate markers or partners in crime? Kidney International , 2015; Jun;87(6):1092-4.

72. Vanholder, R.; Glorieux, G.; Eloot, S. Once upon a time in dialysis: The last days of kt/v? 88, 460-465. Kidney Int. 2015 Sep;88(3):460-5.

73. A.H. Berg, C. Drechsler, J. Wenger, R. Buccafusca, T. Hod, S. Kalim, W. Ramma, S.M. Parikh, H. Steen, D.J. Friedman, J. Danziger, C. Wanner, R. Thadhani, S.A. Karumanchi, Carbamylation of serum albumin as a risk factor for mortality in patients with kidney failure, Sci. Transl. Med. 2013 Mar 6;5(175):175ra29.

74. S. Jaisson, L. Gorisse, C. Pietrement, P. Gillery, Quantification of plasma homocitrulline using hydrophilic interaction liquid chromatography (HILIC) coupled to tandem mass spectrometry, Anal. Bioanal. Chem. 2012; 1635-1641.

75. S. Delanghe, A. Moerman, A. Pletinck, E. Schepers, G. Glorieux, W. Van Biesen, J.R. Delanghe, M.M. Speeckaert, Quantification of carbamylated albumin in serum based on capillary electrophoresis, Electrophoresis . 2017; 2135-2140.

76. Desmons, S. Jaisson, C. Pietrement, P. Rieu, A. Wynckel, P. Gillery, Homocitrulline: a new marker for differentiating acute from chronic renal failure, Clin. Chem. Lab. Med. 2016 Jan;54(1):73-9.

77. Kwan, J. T., Carr, E. C., Bending, M. R., and Barron, J. L. Determination of carbamylated hemoglobin by highperformance liquid chromatography. Clinical Chemistry, 1990; 36(4):607-610.

78. Stim, J., Shaykh, M., Anwar, F., Ansari, A., Arruda, J. A., and Dunea, GFactors determining hemoglobin carbamylation in renal failure. Kidney Int . 1995;48(5) :1605-1610.

79. Tarif, N., Shaykh, M., Stim, J., Arruda, J. A., and Dunea, G. Carbamylated hemoglobin in hemodialysis patients. Am J Kidney Dis 1997 Sep;30(3):361-5.

80. Laaksonen S, Metsärinne K, Voipio-Pulkki LM, et al. Neurophysiologic parameters and symptoms in chronic renal failure. Muscle Nerve 2002;25:884-90.

81. Krishnan AV, Phoon RK, Pussell BA, Charlesworth JA, Kiernan MC. Sensory nerve excitability and neuropathy in end stage kidney disease. J Neurol Neurosurg Psychiatry. 2006;77:548-51.

82. American Academy of Neurology guideline summary for clinicians: detection, diagnosis and management of dementia. 2013. http://tools.aan.com/professionals/practice/pdfs/dementia_guideline.

83. K/DOQI clinical practice guidelines for chronic kidney disease: Evaluation, classification, and stratification . American Journal of Kidney Diseases 2002; 39(2):S14S266 .2002;

84. KDOQI US Commentary on the 2012 KDIGO Clinical Practice Guideline for the Evaluation and Management of CKD American Journal of Kidney Diseases . 2014; 63( 5) : 713-735.
85. Juncos L.A., Chandrashekar K., Juncos L.I. Cognitive Impairment/Dementia in Chronic Renal Disease. In: Gargiulo P., Mesones-Arroyo H. (eds) Psychiatry and Neuroscience Update. 2017; Vol. II. Springer, Cham

86. Hays R, Kallich J, Mapes D, et al. Kidney Disease Quality of Life Short Form (KDQOL-SFTM), Version 1.3: A Manual for Use and Scoring. Santa Monica, CA: RANDP-, 19947994.

87. Petersen RC. Mild cognitive impairment. N Engl J Med. 2011;364(23):2227-34

88. Vicenzini E., Ricciardi M.C., Altieri M., Puccinelli F., Bonaffini N., Di Piero V., Lenzi G.L. Cerebrovascular reactivity in degenerative and vascular dementia: A transcranial doppler study. Eur. Neurol. 2007;58:84-89

89. Folstein MF, Folstein SE, McHugh PR. "Mini-mental state". A practical method for grading the cognitive state of patients for the clinician. J Psychiatr Res. 1975;12(3):189-98.

90. Cornblath DR, Chaudhry V, Carter K, et al. Total neuropathy score: validation and reliability study. Neurology 1999;53:1660.

91. Shende VS, Sharma RD, Pawar SM, Waghmare SN. A study of median nerve entrapment neuropathy at wrist in uremic patients. Indian J Nephrol. 2015. 25:229-33.

92. Issar T, Arnold R, Kwai NCG, et al. The utility of the Total Neuropathy Score as an instrument to assess neuropathy severity in chronic kidney disease: A validation study. Clin Neurophysiol. 2018;129:889-94.

93. England JD, Gronseth GS, Franklin G, et al. Distal symmetric polyneuropathy: a definition for clinical research: report of the American Academy of Neurology, the American Association of Electrodiagnostic Medicine, and the American Academy of Physical Medicine and Rehabilitation. Neurology. 2005;64:199-207.

94. Smyth B, et al. Randomised controlled trial of the impact of haemodiafiltration on uraemic neuropathy: FINESSE study protocol BMJ Open. 2019 Jan 15;9(1):e023736.

95. Doulgerakis D, Moyssakis I, Kapelios CJ, Eleftheriadou I, Chorepsima S, Michail S, Tentolouris N. Cardiac autonomic neuropathy predicts all-cause and cardiovascular mortality in patients with end-stage renal failure: a 5year prospective study. Kidney Int Rep. 2017; 02:686694

96. Badarau S, Siriopol D, Drugus D, et al. Electrocardiogram abnormalities and heart rate variability in predicting mortality and cardiovascular events among hemodialyzed patients. Int Urol Nephrol. 2015;47:1703-1708.

97. Vaziri, N.D. Effect of synbiotic therapy on gut-derived uremic toxins and the intestinal microbiome in patients with ckd. Clin. J. Am. Soc. Nephrol. CJASN 2016, 11, 199-201.

98. Ranganathan N. Reality of "Enteric Dialysis ®" with Probiotics and Prebiotics to Delay the Need of Conventional Dialysis . J Nephrol Ther. 2018, 8: 319.

99. Yamaguchi J, Tanaka T, Inagi R. Effect of AST-120 in Chronic Kidney Disease Treatment: Still a Controversy?Nephron. 2017;135(3):201-206.

100.Locatelli F, Canaud B, Eckardt KU, Stenvinkel P, Wanner C, Zoccali C. Oxidative stress in end-stage renal 
disease: an emerging threat to patient outcome. Nephrol Dial Transplant. 2003;18(7):1272-80.

101.J.J. Carrero, P. Stenvinkel, L. Cuppari, T.A. Ikizler, K. Kalantar-Zadeh, G. Kaysen, W.E. Mitch, S.R. Price, C. Wanner, A.Y. Wang, P. ter Wee, H.A. Franch, Etiology of the protein-energy wasting syndrome in chronic kidney disease: a consensus statement from the International Society of Renal Nutrition and Metabolism (ISRNM), J. Ren. Nutr. 2013 Mar;23(2):77-90.

102.S. Kalim, G. Ortiz, C.A. Trottier, J.J. Deferio, S.A. Karumanchi, R.I. Thadhani, A.H. Berg, The effects of parenteral amino acid therapy on protein carbamylation in maintenance hemodialysis patients, J. Ren. Nutr. 2015 Jul;25(4):388-92.

103. Stosovic M, Nikolic A, Stanojevic M, et al. Nerve conduction studies and prediction of mortality in hemodialysis patients. Ren Fail 2008;30:695-9.

104.Jurcić D, Bilić A, Schwarz D, et al. Clinical course of uremic neuropathy in long-term hemodialysis. Coll Antropol 2008;32:771-5.

105.Ho DT, Rodig NM, Kim HB, Lidov HGW, Shapiro FD, Raju GP, Kang PB. Rapid reversal of uremic neuropathy following renal transplantation in an adolescent. Pediatr Transplant 2012; 16: E296-E300.

Figure1. Etiopathogenesis and conseqences of neurological complications in $\mathrm{CRF}$ 
VASCULAR CAUSALITY OF URAEMIC NEUROPATHY

NON VASCULAR CAUSALITY OF URAEMIC NEUROPATHY

\section{TRADITIONAL RISK FACTORS}

Thypertension, diabetes mellitus, dyslipidemia

NON-TRADITIONAL RISK FACTORS

- inflammation,

oxidative stress

endothelial dysfunction

hemostasis disorders

vascular calcifications

By direct influence on cerebral microcirculation,

(increased the risk of cerebrovascular events),

by induction of the peripheral vascular network,

(change the general hemodynamics).

by erosion and increased permeability

of the cerebral-spinal-blood barrier

(influx of uremic toxins)

UREMIC TOXIC TISSUE LESION

group of small water-soluble compounds
(guanidines, ADMA, TMA, myoinositol, polyamines),

group of protein-bound compounds

(kinurenin, AG, phenyl acetic acid, quinolineic acid)

- group of medium molecules

( $\beta 2$-microglobulin, cystatin $C$, ghrelin, neuropeptide $Y$,

methionine-enkephalin, parathyroid hormone).

\section{CUMULATIVE METABOLIC TISSUE LESION}

- accumulation of degenerative products of carbamylation

- accumulation of degenerative products of other NEPTMs

By side effects of oxidative-inflammatory mediators on nervous tissue (microglia, astrocytes, neurons) and signal transmission

NEURODEGENERATIVE SEQUELAES OF URAEMIC NEUROPATHY

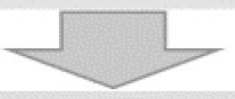

PREMATURE LOSS OF FUNCTIONAL INTEGRITY OF THE NERVOUS SYSTEM

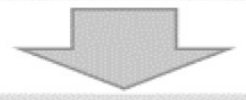

PREMATURE INVOLUTION OF THE NERVOUS SYSTEM

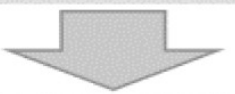

INDICATOR OF THE PROCESS OF ACCELERATED, NONPHYSIOLOGICAL AGING

Figure 2. Carbamylation promotes molecular aging in CRF

through changes in protein function and catabolism 
NON-ENZYMATIC POSTTRANSLATIONAL MODIFICATION (NEPTM) OF PROTEINS

(glycation, oxidation, carbamylation, phosphorylation, nitration, citrullination, deamidation)

NATURAL BIOLOGICAL REGULATORS OF PROTEIN INTERACTIONS AND TURNOVER

interfere with receptor recognition, enzymatic and hormonal activity proteolytic capacity

\section{IN PHYSIOLOGICAL CIRCUMSTANCES}

NEPTM molecular conformations induce irreversible changes in biological properties of proteins gradual attenuation of functions and tissue degeneration PHYSIOLOGICAL AGING

HEALTHY CONITION regular NEPTM of proteins

PHYSIOLOGICAL AGING

IN PATHOPHYSIOLOGICAL CIRCUMSTANCES OF MANY DISEASES

increased activity of NEPTM - increases the formation and accumulation degradation products: occurrence and progression of complications of these diseases

ACCELERATES THE PROCESS OF INVOLUTION

NON-PHYSIOLOGICAL AGING

Figure 3. The identification and therapeutic control of the accelerated involution substrate, responsible for the amplification of not only neurological 
but also general degenerative processes in CRF, is attractive in the context of the well-known attitude towards aging.

URAEMIC NEUROPATHY- FIRST CLINICAL INDICATOR OF CUMULATIVE METABOLIC LESION

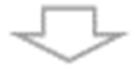

IDENTIFICATION OF PREMATURE NEURODEGENERATIVE PROCESS

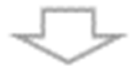

THERAPEUTIC CONTROL OF AMPLIFICATION OF GENERAL DEGENERATIVE PROCESS IN CRF
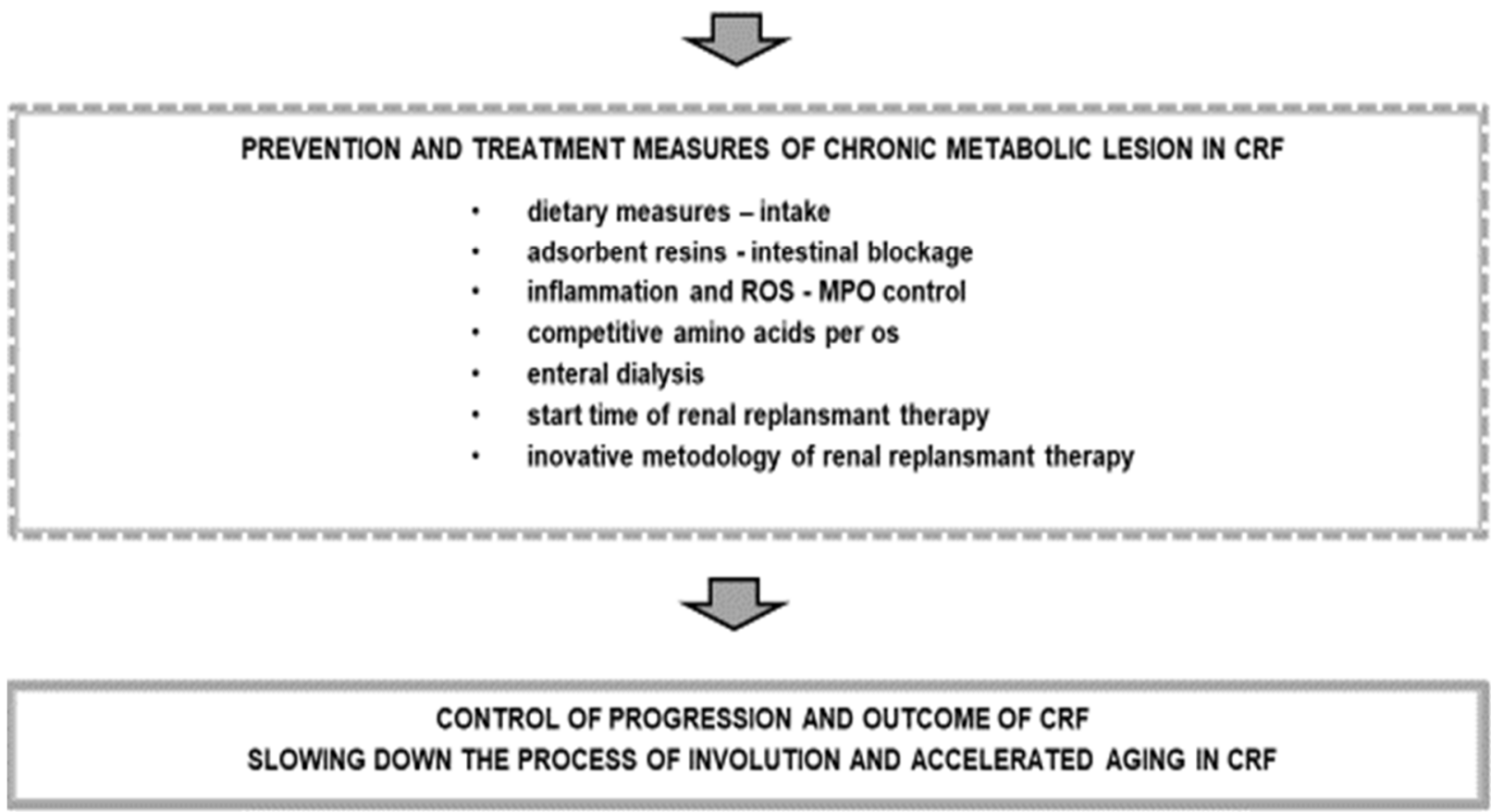
Table 1. Structured neurological examination questionnaire for assessing the severity of uremic neuropathy: structural testing with defined earlier "first processing" on a level scale and regularly adopted dynamics during CRF

STRUCTURED NEUROLOGKAL EXAMINATIOW QUESTIONNAIRE TO ASSESS THE SEVERITY OF UREMIC NEUROPATHY

UREMIC NEUROPATHY OF CENTRAL NERVOSUS SYSTEM

MOOTFIEO FORMAL KEURO-PSYCHOLOGICOL EVALUATION

- Cock Drawing Test

- Minimental Test

- Clinical Dementiascale

UREMIC NEUROPATHY OF PERIFERAL NERVOSUSSYSTEM

MOOFIED TOTAL NEUROPATHYSCORE (TRS) ASSESSMENT

NEUROPATHX SMMPTOM SCORE (NSS)
For clinical assessment of deficits of

cognitive impdirment

Smemory, exacutive function, attention, concentration,

perception and / or languageskills]

and dementia

\{coenitive orsfunction and behwioral disorders).

elextrophrsiobgical fincings - electoencephalography (EES)

Indudes symptoms signs and elextrophrsological finding electromiography (EMG) and nerve conductiontestine

amplitudes of the tibial and sural nerve

The questionnaire identflies the presence or absence of symptoms in three categores and assigns one point for each symptom present

[four motor, three negative and two positwe sensors]

UREMIC NEUROPATHY OF AUTONOMIC NERVOSUS 5 YSTEM

- assessment of papillay, vascular and cardiacenenes

- variability of heart rate and blood pressure in relation to the respiratory cyle,

Routine modified clinical assessment electocaresography $\{E C G)$

- identifcation of intradialysis hyporension and postural changer in blood ocessure

- effect of manipulation of the Valsalua mansuver

proarimogenicity detection

- detection of impotence, dysfunction of eastric and bladder moctity, sweating disorder

\section{AVAILABIE BIOMARXERS}

$\mathrm{CHb}$

cLDLs

Carbamyated amino acids

Plasma carbamylated proteins

Protein-bound homocaruline
For the assessment of protein carbamylation 